\title{
A autonomia financeira das universidades
}

José Goldemberg

Ex-reitor da Universidade de São Paulo (USP) e ex-ministro da Educação

\section{Resumo}

Intervenção crítica de José Goldemberg.

Palavras-chave Autonomia Universitária - Administração - Economia política - Universidade de São Paulo.

Submissão

24/04/2020 Publicação

06/05/2020 
criação de uma Comissão Parlamentar de Inquérito na Assembleia Legislativa para
apurar investigações dos gastos das universidades deu lugar a dúvidas sobre a
extensão real da autonomia universitária no nosso Estado.

O artigo 207 da Constituição Federal de 1988 determina que "as universidades gozam de autonomia didático-científica, administrativa e de gestão financeira e patrimonial”. Até então, a autonomia financeira das universidades - como é o caso ainda das federais - era puramente retórica.

Em 2 de fevereiro de 1989, o Governador do Estado de São Paulo, Orestes Quércia, assinou o decreto 29598 que "dispõe sobre providências visando a autonomia universitária”.

$\mathrm{O}$ decreto estabeleceu que "as liberações mensais de recurso do Tesouro a estas instituições (as três universidades do Estado, USP, UNICAMP e UNESP) deverão respeitar o percentual global de $8,4 \%$ da arrecadação do ICMS”. O decreto estabeleceu também que os Conselhos de Reitores das universidades estaduais paulistas fixarão os critérios de execução orçamentária, incluindo os relativos à política salarial do seu pessoal docente, técnico e administrativo.

A autonomia financeira determinada pelo decreto não significa soberania, os objetivos das universidades são fixados em sua lei de criação e o orçamento é determinado pela lei orçamentária do Estado. A autonomia é de gestão. Com ela, as universidades passam a ter a autoridade para se organizar internamente, determinar as suas prioridades, escolher seus dirigentes (exceto o Reitor, que é escolhido pelo governador de uma lista tríplice preparada pelo Conselho Universitário) e planejar seu desenvolvimento, já que seus recursos são vinculados dependendo apenas da evolução do ICMS.

Com isso, acabou a saga dos reitores das universidades estaduais em busca de recursos adicionais e suplementações para cobrir as despesas num período em que a inflação atingia níveis superiores a 50\%. Mais ainda, permitiu estruturar a carreira docente, dos técnicos e do pessoal administrativo que atendessem às características próprias das universidades e que não são as mesmas que outras organizações governamentais.

Os efeitos positivos do decreto do governador Quércia se tornaram evidentes ao longo dos últimos 30 anos.

O que ocorreu em São Paulo, com a autonomia das universidades é, portanto, um exemplo importante de gestão pública de sucesso, o que contrasta radicalmente com as dificuldades das universidades federais, nas quais a interferência do governo é muito grande.

$24 \cdot$ ano XI, n. I6, $2020 \cdot \mathrm{ISSN} 2179-5487$ 
O uso de recursos é microgerenciado pelo Ministério da Educação, por necessidade de fazer contingenciamentos decorrentes da queda da arrecadação ou até por razões ideológicas. Só para dar um exemplo, até a escolha de pró-reitores tem que ser decidida no nível da Presidência da República.

Pergunta-se frequentemente quais os fatores que levaram o governador Quércia a assinar o decreto da autonomia financeira, abrindo mão de poder dos órgãos centrais do Estado.

Existem ao menos dois fatores que levaram a esta decisão:

Em primeiro lugar, a presença no governo de secretários esclarecidos como Luiz Gonzaga Belluzzo (Ciência e Tecnologia) e Frederico Mazzucheli (Economia e Planejamento).

Em segundo lugar, os reitores combativos: Paulo Renato Souza (UNICAMP), Jorge Nagle (UNESP) e José Goldemberg (USP), que haviam influído na redação do artigo 207 da Constituição e convencido o então deputado Mario Covas (relator da Constituição) a retirar do artigo 207 a frase "nos termos da lei” que constava dele originalmente. Sua manutenção significaria que a autonomia financeira seria regulada em lei, no futuro, o que não ocorreu até hoje nas universidades federais.

Sob o ponto de vista político, o decreto teve como consequência imediata tornar as reitorias o foco das demonstrações de estudantes, funcionários e professores (que eram frequentes na ocasião) e afastá-las do Palácio dos Bandeirantes. O peso que este fato teve na decisão do governador Quércia, é difícil de ser avaliado.

Um dos únicos aspectos controvertidos do decreto de autonomia é o artigo 2o (parágrafo $2^{2}$ ) que "recomenda" que as despesas com pessoal não excedam a $75 \%$ dos valores liberados pelo Governo.

Argumentam alguns que se pode tolerar gastos com pessoal maiores que $75 \%$ nas universidades que recebem recursos de outras fontes para bolsas de estudo e pesquisas científicas. Estas verbas, contudo, são “marcadas”, isto é, direcionadas para programas específicos, têm duração limitada e não se destinam a salários de funcionários, que são permanentes.

Este limite de $75 \%$ foi obedecido em alguns períodos e não em outros, dependendo dos reitores que não resistiram a demandas corporativas para aumento de salários. Até 2oıo, não houve crises sérias devido a este problema, mas, a partir daí, houve um descontrole fiscal nas universidades com aumentos, gratificações e outras benesses incorporadas aos salários que se tornaram irreversíveis. A crise econômica e a queda da arrecadação do ICMS fizeram com que as despesas com pessoal chegassem a mais Ioo\% dos valores recebidos do Tesouro.

A partir de 20I4, o Reitor da USP, Antonio Zago, enfrentou esta crise com determinação, através de um programa de aposentadoria voluntária e outras medidas de economia, que levaram a USP a reequilibrar suas contas com despesas de pessoal abaixo de 
REVISTA ANGELUS NOVUS

90\%. Além disso, a USP criou um sistema de gestão orçamentária que é um exemplar sistema de responsabilidade fiscal. A UNICAMP e a UNESP ainda estão no processo de recuperação.

O fortalecimento do modelo de gestão das universidades paulistas é imperativo para que crises recorrentes não comprometam a excelência de instituições tão duramente conquistadas. 